middle class became the main recipient of the rent. During this period, Venezuelan society has reached the highest level of its stability and prosperity. At the turn of the $20^{\text {th }}$ and $21^{\text {st }}$ centuries, the poorest strata of Venezuelan society have become the new beneficiaries of the resource rent. At the same time, a social conflict was growing in the country between strata of the population who received their share of the resource rent and citizens who did not receive their share.

The possibilities for further development of this model have already been exhausted. The social crisis led to the degradation of the country's economy and oil industry. The amount of oil rent is already insufficient to ensure broad electoral support for the current government. The socio-political model of Venezuela has entered the stage of a deep crisis.

Keywords: petroetatic model (petroestado), Venezuela, crisis, social stratum, electoral support

ФАЙНШМИДТ Роман Иосифович - аспирант кафедры политологии и политического управления Института общественных наук Российской академии народного хозяйства и государственной службы при Президенте РФ (119571, Россия, г. Москва, пр-кт Вернадского, 82; faynshmidt-ri@ ranepa.ru)

\title{
ФАКТОРЫ РАДИКАЛИЗАЦИИ ИСЛАМА В ИНДОНЕЗИИ В КОНЦЕ ХХ - НАЧАЛЕ XXI в.
}

\begin{abstract}
Аннотация. В конце 1990-х - начале нулевых гг. в Индонезии получили распространение радикальные формы ислама, которые в ряде случаев были связаны с возникновением исламистских террористических группировок в различных частях страны. Подобное явление стало неожиданностью для международного сообщества, традиционно отождествляющего радикальный ислам с Ближним Востоком. Тем не менее развитие радикального ислама в Индонезии и его проявление в подобном формате порождено целым комплексом причин, рассмотренных в рамках данной статьи.
\end{abstract}

Ключевые слова: радикальный ислам, Индонезия, исламизм, Джемаа Исламия, терроризм

$\mathrm{K}$ началу XXI в. Индонезия является крупнейшим в мире государством по численности населения, исповедующего ислам. Так, в 2010 г. из 237,64 млн населения страны 207,18 млн относили себя к мусульманам ${ }^{1}$. В то же время Индонезия также известна и распространением радикальных форм ислама, нередко выражающихся в террористической активности отдельных группировок. Наибольшую известность среди террористических группировок получила Джемаа Исламия (Jemaah Islamiyah), известная своими связями с Аль-Каидой (запрещена на территории РФ), а также серией взрывов на о. Бали в октябре 2002 г. с общей численностью жертв более 200 чел. Кроме Джемаа Исламия, распространены такие сетевые группировки, как Джамаа Аншарут Таухид (Jamaah Ansharut Tauhid), Ласкар Джихад (Laskar Jihad), Муджахидин Индонезия Тимур (Mujahidin Indonesia Timur), Муджахидин КОМПАК (Mujahedeen KOMРАK) и ряд других. Иными словами, проблема исламского радикализма, в т.ч. и с участием вооруженных группировок, имеет особую актуальность для Индонезии, а само возникновение данного явления обусловлено целым комплексом факторов.

Прежде всего, следует обозначить, что Индонезия является полиэтническим и многоконфессиональным обществом. В число крупнейших этниче-

${ }^{1}$ Kewarganegaraan, Suku Bangsa, Agama, dan Bahasa Sehari-hari Penduduk Indonesia - Hasil Sensus Penduduk 2010 ['Nationality, Ethnicity, Religion, and Daily Language of Indonesian Population - Results of the 2010 Census']. Jakarta: Badan Pusat Statistik (BPS - Statistics Indonesia). October 2011. Р. 42-43 (на индонез. яз). 
ских групп входят яванцы, сунданцы, батаки, мадурцы, батаки, малайцы и др. Многоконфессиональный характер Индонезии проявляется в отсутствии единой государственной религии и в признании равенства между шестью религиями - исламом, католическим христианством, протестантским христианством, буддизмом, индуизмом и конфуцианством. В ряде случаев можно обнаружить доминирование одной религии в рамках отдельной этнической группы: например, балийцы в большинстве своем исповедуют индуизм. В то же время в ряде регионов имели место столкновения между представителями различных конфессиональных групп, примером чему являются вооруженные столкновения между протестантами и мусульманами в период с 1998 по 2001 г. в Центральном Сулавеси, в округе Посо. При этом со стороны мусульман атаки совершались отмеченными выше группировками, такими как Ласкар Джихад и Муджахид КОМПАК.

Во-первых, необходимо отдельно выделить, что и ислам в Индонезии не представляет собой монолитную структуру, хотя абсолютное большинство приверженцев ислама в стране являются суннитами при наличии небольших сообществ шиитов и ахмади. Мусульмане-сунниты связаны с различными исламскими организациями, крупнейшие из которых, Нахдатул улама (организация традиционного индонезийского ислама) и Мухаммадийя (организация исламского модернизма), насчитывают 30-40 млн чел. [Menchik 2014: 363]. Если обе вышеперечисленные организации отличаются толерантным отношением к другим конфессиям и критикуют любые формы проявления радикализма, то ряд отдельных организаций, например Фронт защитников ислама (FPI - Front Pembela Islam), в своей повестке активно выступают против других конфессий, что нередко выражается и в погромах отдельных групп (например, ахмади и христиан) или учреждений (например, атака на Национальный альянс за свободу веры и религии в Джакарте в 2008 г.). Несмотря на радикализм лозунгов и действий, FPI был окончательно запрещен только в декабре 2020 г.

В качестве катализатора распространения исламского радикализма и появления вооруженных группировок можно выделить проблемы социально-экономического характера. Индонезия долгое время относилась к группе стран с доходом ниже среднего - меньше 4 тыс. долл. на душу населения, и только в 2020 г. ей удалось перейти в группу с доходом выше среднего ${ }^{1}$. Отдельной проблемой является также и региональное неравенство. Если в Джакарте подушевой ВРП в 2019 г. составлял более 19 тыс. долл. США, то, например, в провинции Западная Нуса-Тенгара этот показатель составлял менее 1900 долларов США, т.е. более чем в 10 раз меньше по сравнению со столицей ${ }^{2}$. При этом в 24 провинциях из 34 ВВП на душу населения был меньше 4 тыс. долл. США в год ${ }^{3}$. При этом к бедным провинциям можно отнести как мусульманские Ачех и Западную Нуса-Тенгара, так и преимущественно христианскую Восточную Нуса-Тенгара.

В-третьих, особое значение имеют особенности исторического развития Индонезии в первые годы после объявления независимости. Уже в период борьбы с голландскими колонизаторами в период с 1945 по 1950 г. обозначилась отдельная исламистская сила, известная как Даруль Ислам (Земля

${ }^{1}$ Hamadeh N., Serajuddin U. New World Bank country classifications by income level: 20202021. - The World Bank Group. 01.07.2020. URL: https://blogs.worldbank.org/opendata/newworld-bank-country-classifications-income-level-2020-2021 (accessed 18.04.2021).

2 Produk Domestik Regional Bruto Provinsi-Provinsi di Indonesia Menurut Lapangan Usaha 20162020. Jakarta: Badan Pusat Statistik (BPS - Statistics Indonesia). 2021. P. 19 (на индонез. яз.).

3 Там же. 
ислама). Даруль Ислам активно продвигал вопрос внедрения шариатского права и исламизации общества, что вызвало недовольство со стороны индонезийских националистов, таких как Сукарно и М. Хатта. Противоречия трансформировались в серию мятежей и столкновений в течение 1950-х гг., в ходе которых движение Даруль Ислам провозгласило создание Исламского государства Индонезии (Negara Islam Indonesia), не подчиняющегося законам и Конституции Республики Индонезия. Данное образование было в значительной степени фрагментированным и включало в себя отдельные группы мятежников, контролировавших небольшие территории в Западной Яве, южной части Сулавеси, на юге Калимантана и на территории современной провинции Ачех. По мнению специалиста по истории и политическим процессам Индонезии Л.М. Ефимовой, современные формы радикального ислама Индонезии следует рассматривать как продолжение Даруль Ислама и его опыта противодействия индонезийской власти [Ефимова 2011: 93].

В условиях развития «нового порядка» - авторитарного режима под предводительством генерала Сухарто и запрета на инакомыслие в обществе обсуждение ислама и его роли в обществе стало подпольным и концентрировалось вокруг мечетей, медресе, а также религиозных школ-интернатов, известных как пондоки или песантрены. Именно эти учреждения становились точками распространениями исламской протестной повестки. В то же время в некоторых пондоках активно продвигалась идея воссоздания Исламского государства Индонезии и изучалась литература, связанная с радикальным исламом. Наибольшую известность среди подобных школ получил песантрен Нгруки (второе название - Исламская школа Аль-Мукмин), которую основал Абу Бакар Башир, в будущем основатель наиболее опасной джихадистской структуры Джемаа Исламия. Именно из пондока Нгруки происходит основная часть боевиков данной террористической группировки. Развитие подпольного исламского протеста породило движение «усрох» (usroh в пер. с араб. - семья). Движение характеризовалось формированием в различных частях страны обособленных сообществ из 10-15 человек, живущих исключительно по шариатским законам и традициям ислама. Данный концепт к концу XX в. становится основой распространения сетей подпольных террористических ячеек целого ряда организаций [Hairgrove, McLeod 2008: 408].

Уже к 1976 г. на основе отдельных фрагментов Даруль Ислама формируется новая террористическая группировка под названием Командо Джихад (Komando Jihad). Создание данной организации стало возможным благодаря появлению исламизированной молодежи и роста численности сочувствующих. Цель Командо Джихада заключалась в организации серии терактов по стране, которые, согласно их ожиданиям, привели бы к крушению режима Сухарто и началу исламской революции по всей стране [Ефимова 2011: 96-97]. В итоге к середине 1980-х гг. деятельность Командо Джихада привела к росту джихадизма и окончательному оформлению мелких террористических групп, которые фактически были продуктом обозначенного ранее движения «усрох».

В качестве четвертой причины следует подчеркнуть внешний фактор, а именно поддержку со стороны отдельных международных игроков, среди которых в наибольшей степени выделяется Саудовская Аравия. Так, индонезийские власти уже в начале 1980-х гг. позволили Саудовской Аравии предоставлять стипендии на обучение в религиозных учреждениях Королевства, например, в Исламском университете Медины. В университетах Саудовской Аравии индонезийская религиозная молодежь изучала салафитский ислам и труды Мухаммада ибн Абд аль-Ваххаба, основателя ваххабизма, радикального 
исламского течения. Отдельной линией саудовского влияния стала поддержка религиозных учреждений внутри самой Индонезии. Особое внимание при этом уделялось школам-интернатам (пондокам) и медресе, которые получали финансирование и учебную литературу из КСА, где ислам рассматривался в ваххабитском восприятии. Одним из примеров религиозных школ, получавших саудовскую поддержку, был уже отмеченный выше песантрен Нгруки ${ }^{1}$. В то же время Саудовская Аравия с 1980 г. имела в Джакарте собственный Институт изучения ислама и арабского языка, в котором активно преподавались догматы исламского фундаментализма и который имел прямую связь с Исламским институтом имама Мухаммада ибн Сауда в Эр-Рияде 2 Отдельным направлением являлась поддержка молодежных организаций, которые также служили инструментом продвижения ваххабитской идеологии и индоктринации молодого поколения. В итоге молодежные организации, имевшие связи с КСА, становились основой отдельных террористических ячеек. Например, молодежное просветительское движение Джамаа Ихьяус Сунна (Jamaah Ihyaus Sunnah), продвигавшее салафитские и ваххабитские взгляды и финансируемое из Саудовской Аравии, превратилось в сеть террористических организаций, одной из которых была Ласкар Джихад на Молуккских островах [Bräuchler 2004: 269].

Последним фактором, обусловившим значительный рост исламского радикализма в индонезийском обществе, является комплексный социально-экономический и политический кризис. Экономический кризис был связан с распространением Азиатского финансового кризиса в 1997-1998 гг. и привел к крушению авторитарного политического режима Сухарто, за которым последовала слабо контролируемая демократизация всей политической системы страны. Растущая нестабильность, политическая неопределенность и экономическая стагнация с выросшей безработицей и неудовлетворенностью жизнью заставляют исламистские силы приступить к активным действиям и распространять исламистскую пропаганду для привлечения новых последователей и бойцов. Кроме того, сразу после ухода Сухарто из эмиграции возвращаются отдельные исламистские деятели (например, А. Бакар Башир из Малайзии) в надежде использовать ситуацию для получения власти и превращения страны в исламское государство, имея в качестве успешной модели Иранскую революцию 1979 г. Из-за падения авторитарного режима значительно ослабевает преследование исламских радикалов и членов террористических организаций.

Таким образом, можно выделить пять причин, способствовавших росту радикализма и экстремизма в Индонезии в конце XX - начале XXI в. Эти причины связаны со сложной этнической и конфессиональной структурой индонезийского общества, относительно низким уровнем социально-экономического развития и высокой степенью неравенства по доходам, наличием исторических предпосылок к развитию исламских радикальных группировок, присутствием внешнего фактора, влияющего на распространение радикальных учений ислама. и, наконец, с возникновением системного политического и экономического кризиса в 1998 г. Совокупность этих факторов в итоге привела к росту террористической активности в нулевых годах, а нерешенность

1 Varagur K. Saudi Arabia Quietly Spreads its Brand of Puritanical Islam in Indonesia. - The Voice of America. 17.01.2017. URL: https://www.voanews.com/east-asia-pacific/saudi-arabiaquietly-spreads-its-brand-puritanical-islam-indonesia (accessed 04.07.2021).

2 Varagur K. How Saudi Arabia's Religious Project Transformed Indonesia. - The Guardian. 16.04.2020. URL: https://www.theguardian.com/news/2020/apr/16/how-saudi-arabia-religiousproject-transformed-indonesia-islam (accessed 04.07.2021). 
ряда проблем, связанных с этими факторами, может привести к последующей радикализации ислама на современном этапе развития Индонезии.

\title{
Список литературы
}

Ефимова Л.М. 2011. Исламский экстремизм в Индонезии. - Юго-Восточная Азия: актуальные проблемы развития. Вып. XVII. С. 90-105.

Bräuchler B. 2004. Islamic Radicalism Online: The Moluccan Mission of the Laskar Jihad in Cyberspace. - The Australian Journal of Anthropology. Vol. 15. Is. 3. P. 267285.

Hairgrove F., McLeod D.M. 2008. Circles Drawing toward High Risk Activism: The Use of Usroh and Halaqa in Islamist Radical Movements. - Studies in Conflict \& Terrorism. Vol. 31. Is. 5. P. 399-411.

Menchik J. 2014. The Co-evolution of Sacred and Secular: Islamic Law and Family Planning in Indonesia - South East Asia Research. Vol. 22. No. 3. P. 359-378.

FAINSHMIDT Roman losifovich, postgraduate student at the Chair of Political Science and Public Administration, Institute for Social Sciences, Russian Presidential Academy of National Economy and Public Administration (RANEPA) (82 Vernadskogo Ave, Moscow, Russia, 119571; faynshmidt-ri@ranepa.ru)

\section{FACTORS OF ISLAMIC RADICALIZATION IN INDONESIA AT THE END OF THE $20^{\text {TH }}$ - THE BEGINNING OF $21^{\text {ST }}$ CENTURY}

\begin{abstract}
In the late 1990s - early 2000s, in Indonesia, radical forms of Islam significantly spread what in some cases was reflected by the emergence of Islamist terrorist groups in various parts of the country. This phenomenon came as a surprise to the international community, which traditionally equated radical Islam with the Middle East issues. Nevertheless, a whole complex of reasons outlined in this article generated the development of radical Islam in Indonesia and its manifestation in the given format.
\end{abstract}

Keywords: radical Islam, Indonesia, Islamism, Jemaah Islamiya, terrorism 